\title{
Peningkatan Kemampuan Mengenal Lima Huruf Vokal Melalui Media Bola Huruf Pada Anak Usia 3-4 Tahun
}

\author{
Siti Karoma ${ }^{1}$
}

Abstract: This research is motivated by the difficulty of children aged 3-4 years in recognizing five vowels that is often children fnd it difficult to mention and distinguish vowels such as the letter " $e$ ", " $u$ " and "o". While the letters that are always emembered by children are the letters " $i$ " and the letter " $a$ ". This study aims to describe the learning process by using letter ball media in order to improve the ability to recognize five vowels in children aged 3-4 years and to find out the increased ability to recognize five vowel letters the use of lette ball media in children aged 3-4 years. The method used in this research is classroom action research. This research consisted of pre cycle, cycle I, cyle II, cyle III. Data collection techniques in this study used observation, interviews, non-test assessment, and documentation. The analysis technique in this study uses quantitative descriptive analysis, the results of this study are the se of letter ball media developed very well in cycle III by using letter ball media plus media decorating plastic cups.

Keywords: recognize five vowels, letter ball media, children aged 3-4 years

Abstrak: Penelitian ini di latar belakangi oleh kesulitan anak usia 3-4 tahun dalam mengenal lima huruf vokal yaitu seringkali anak merasa kesulitan dalam menyebutkan dan membedakan huruf vokal seperti huruf "e", "u", dan huruf "o". Sedangkan huruf yang selalu di ingat oleh anak adalah huruf " $i$ " dan huruf "a". Penelitian ini bertujuan untuk mendeskripsikan proses pembelajaran dengan penggunaan media bola huruf dalam rangka meningkatkan kemampuan mengenal lima huruf vokal pada anak usia 3-4 tahun dan untuk mengetahui peningkatan kemampuan mengenal lima huruf vokal setelah penggunaan media bola huruf pada anak usia 3-4 tahun. Metode yang digunakan dalam penelitian ini adalah Penelitian Tindakan Kelas. Penelitian ini terdiri dari pra siklus, siklus I, siklus II dan siklus III. Teknik pengumpulan data pada penelitian ini menggunakan observasi, wawancara, penilaian non tes, dan dokumetasi. Teknik analisis pada penelitian ini menggunakan analisis deskriptif kualitatif. Hasil penelitian ini adalah Penggunaan media bola huruf berkembang sangat baik pada siklus III dengan menggunakan media bola huruf dan ditambah media menghias gelas plastik.

Kata kunci: mengenal lima huruf vokal, media bola huruf, anak usia 3-4 tahun 


\section{PENDAHULUAN}

Pendidikan anak usia dini khususnya pada usia 3-4 tahun lebih memfokuskan pada peletakan dasar ke arah pertumbuhan dan perkembangan, yang meliputi perkembangan fisik motorik kasar dan motorik halus, kecerdasan dalam berpikir (perkembangan kognitif), kecerdasan spiritual (perkembangan nilai agama dan moral), kecerdasan sosial emosional, kecerdasan bahasa dan komunikasi sesuai dengan keunikan dan tahap-tahap perkembangan yang dilalui oleh anak usia dini, dan sebaiknya kegiatan yang disediakan harus sesuai perkembangan dan kebutuhan setiap anak (Asmawati, 2017, p.16).

Pengenalan bahasa pada anak usia 3-4 tahun dimulai dari mengenalkan huruf. Salah satu Standart Tingkat Pencapaian Perkembangan Anak pada usia 3-4 tahun adalah mengenal beberapa huruf dari a-z. untuk anak usia 3-4 tahun pengenalan huruf hanya terbatas lima huruf yang sering dikenal atau mereka jumpai. Hal ini disebabkan karena pada anak usia 3-4 tahun adalah masa pengenalan konsep.

Permasalahan yang seringkali terjadi pada anak usia 3-4 tahun dalam mengenal huruf vokal seringkali anak merasa kesulitan dalam menyebutkan dan membedakan huruf vokal seperti huruf "e" dan huruf "o". Sedangkan huruf yang selalu diingat oleh anak adalah huruf "i" dan huruf "a". Dan saat proses belajar mengajar ketika guru menyuruh anak untuk menunjuk huruf secara acak kebanyakan anak masih bingung. Hal ini menunjukkan kemampuan dalam mengenal lima huruf vokal pada anak usia 3-4 tahun rendah atau belum berkembang.

Faktor penyebab dari permasalahan tersebut adalah kurang adanya penekanan dalam mengajarkan setiap huruf, pengenalan huruf pada anak masih sesuai urutan, media dalam mengenalkan huruf kurang bervariasi, dan pengenalan huruf pada anak hanya terbatas pada anak mampu menulis sesuai dengan contoh. Hal ini menyebabkan anak hanya mampu menulis tanpa mengenal konsep huruf yang sesungguhnya.

Mengingat perkembangan bahasa ini sangat penting, maka peneliti dan guru kelas sepakat untuk menggunakan media bola huruf dalam meningkatkan kemampuan mengenal huruf vokal pada anak usia 3-4 tahun. Media bola huruf merupakan media yang akan digunakan dengan tujuan agar anak merasa senang dan tertarik serta antusias dalam pembelajaran sehingga tertanamkan konsep huruf di dalam memorinya, sehingga berangsur-angsur dapat meningkat. Rumusan masalah bagaimana proses pembelajaran dengan penggunaan media bola huruf dalam meningkatkan kemampuan mengenal lima huruf vokal pada anak usia 3-4 tahun? dan bagaimana peningkatan kemampuan mengenal lima huruf vokal setelah penggunaan media bola huruf pada anak usia 3-4 tahun. Tujuan masalah untuk mendeskripsikan proses pembelajaran dengan penggunaan media bola huruf dalam meningkatkan kemampuan mengenal lima huruf vokal pada anak usia 3-4 tahun dan untuk mengetahui peningkatan kemampuan mengenal lima huruf vokal setelah penggunaan media bola huruf pada anak usia 3-4 tahun.

Menurut Munandar kemampuan merupakan daya untuk melakukan suatu tindakan sebagai hasil dari pembawaan (Susanto, 2012, p.97). Kemampuan mengenal huruf juga memiliki arti kemampuan dalam membedakan bentuk-bentuk dan bunyi-bunyi dari setiap huruf serta mampu menyebutkan dan menunjukkan huruf.

Huruf adalah tanda aksara dalam tata tulis yang merupakan anggota abjad yang melambangkan bunyi bahasa. Abjad yang digunakan dalam ejaan bahasa Indonesia terdiri atas 26 huruf a-z (Manan, 1999, p.53).

Menurut team dafa publishing ada beberapa langkah yang tepat dalam mengajari anak mengenal huruf, yaitu: 1) Memperkenalkan berbagai macam bentuk garis, yaitu: garis tegak, datar, miring, lengkung, dan lingkaran; 2) Menunjukkan berbagai macam 
bentuk geometri, yaitu: bentuk segiempat, lingkaran, segitiga, dan setengah lingkaran; 3) Menggabungkan beberapa garis menjadi bentuk huruf, misalnya: garis lengkung /c/ dan garis tegak/i/ menjadi huruf "a,b, d, p, q"; 4) Menyebutkan bunyi dari setiap huruf dengan nada yang berbeda dan menarik, misalnya huruf /s/ bunyinya seperti ular mendesis "sssss"; 5) Menyebutkan nama- nama dari setiap huruf abjad; 6) Menunjukkan namanama dari huruf abjad; 7) Mengurutkan huruf-huruf abjad dari kiri ke kanan; 8) Mengenalkan konsep huruf vokal terlebih dahulu (a, i, u, e, o) kemudian baru huruf konsonan (b, c, d, f, g, h, j, k, l, m, n, p, q, r, s, t, v, w, x, y, z) dengan cara menyenangkan anak (Dafa,2010, p.39).

Pemilihan bola yang digunakan mandi bola dalam pembuatan bola huruf ini dikarenakan bola yang digunakan bola mandi bola merupakan jenis bola yang berbahan plastik yang memiliki corak warna yang beragam dan mencolok sehingga anak lebih tertarik melakukan kegiatan pembelajaran. Juga mudah mencari bahannya serta praktis dalam penyimpanannya, cara pembuatannyapun mudah sehingga siapa saja dapat membuatnya serta dapat disesuaikan dengan tujuan kegiatan pembelajaran.

\section{METODE}

Penelitian ini menggunakan rancangan penelitian tindakan kelas dengan model Kurt Lewin. Konsep pokok penelitian tindakan model Kurt Lewin terdiri dari empat komponen, yaitu: a) perencanaan (planning), b) tindakan (action), c) pengamatan (observing), dan d) refleksi (reflection) (Zainiyati, 2009, p.157). Hubungan antara keempat komponen tersebut menunjukkan sebuah siklus atau kegiatan yang berulang. "Siklus" inilah yang sebetulnya menjadi salah satu ciri utama dari penelitian tindakan kelas. Dengan demikian penelitian tindakan kelas ini terbatas dalam satu kali intervensi saja, tetapi berulang hingga mencapai ketuntasan yang diharapkan.

Lokasi penelitian ini bertempat di Playgroup dan Taman Kanak-kanak Aisyiyah Bustanul Athfal Ketegan Taman Sidoarjo. Subjek penelitian ini adalah anak usia 3-4 tahun 21 anak tahun pelajaran 2017-2018. Dipilih di di Playgroup dan Taman Kanakkanak Aisyiyah Bustanul Athfal Ketegan Taman Sidoarjo dikarenakan berdasarkan hasil pengamatan di kelas Playgroup banyak anak yang belum bisa mengenal lima huruf vokal.

Untuk memperoleh data dalam penelitian ini, peneliti menggunakan beberapa teknik untuk membantu dalam memperoleh data penelitian. Adapun data penelitian tersebut antara lain Observasi, Wawancara, Penilaian Non Tes dan Dokumentasi. Observasi digunakan untuk mengamati kegiatan anak dan kinerja guru pada waktu pembelajaran (Subagyo, 2006, p.62). Wawancara digunakan sebagai metode pengumpulan data dengan mengajukan pertanyaan secara lisan kepada subjek yang diteliti (Subagyo, 2006, p.62). Peneliti mengadakan wawancara dengan guru kelas Playgroup yang bernama Ibu Yusni Ayuningrum. Penilaian Non Tes digunakan untuk mengukur ranah afektif dan psikomotor. Pada penelitian ini, teknik non tes digunakan untuk mengukur kemampuan anak mengenal lima huruf vokal. Dokumentasi adalah mencari data mengenai hal-hal atau variabel yang berupa catatan, transkip, buku, surat kabar, majalah, notulen rapat, lagenda, foto, dan sebagainya (Arikunto, 2010, p.158).

Analisis data adalah analisis data yang telah terkumpul guna mengetahui seberapa besar keberhasilan tindakan dalam penelitian untuk perbaikan belajar siswa (Arikunto, 2010, p.85). Menganalisis data dalam penelitian ini menggunakan deskriptif kualitatif. Beberapa data hasil observasi aktivitas guru dan aktivitas anak terhadap penerapan media bola huruf. hasil observasi aktivitas guru dan aktivitas anak terhadap penerapan media 
bola huruf. Data yang sudah terkumpul kemudian dianalisis. Alat yang digunakan untuk mengobservasi aktivitas guru dan aktivitas anak berupa skor.

Kriteria keberhasilan yang diharapkan peneliti adalah 1) Apabila nilai rata-rata menunjukkan 75 atau lebih, maka anak dikatakan berkembang sesuai harapan, serta media yang digunakan dapat dinyatakan berhasil; 2) Apabila persentase ketuntasan belajar anak menunjukkan $75 \%$ atau lebih, maka anak dikatakan berkembang sesuai harapan, serta media yang digunakan dapat dinyatakan berhasil; 3) Apabila observasi aktivitas guru dan anak menunjukkan 75 atau lebih, maka guru dan anak dikatakan berkembang sesuai harapan, serta media yang digunakan dapat dinyatakan berhasil. Hasil refleksi dan evaluasi pada silkus I digunakan sebagai acuan dalam menyusun perencanaan pada siklus selanjutnya. Jika pada siklus 1 target kriteria pencapaian tindakan belum tercapai, maka berlanjut pada siklus II dan apabila siklus II juga belum tercapai, maka akan dilakukan siklus III sebagai pemantapan hasil siklus I dan II

\section{HASIL PENELITIAN DAN ANALISIS}

Berdasarkan observasi sebelum tindakan bahwa kemampuan mengenal lima huruf vokal anak khususnya pada anak usia 3-4 tahun masih banyak anak yang belum mampu mengenal lima huruf vokal. Rendahnya kemampuan mengenal lima huruf vokal pada anak usia 3-4 tahun, dalam hal ini dibuktikan dari 21 anak yang mampu menunjuk dan menyebutkan huruf vokal hanya ada 4 anak $(19,04 \%)$ memperoleh skor 3 dengan kriteria berkembang sesuai harapan; 11 anak $(52,38 \%)$ memperoleh skor 2 dengan kriteria mulai berkembang; 6 anak $(28,57 \%)$ memperoleh skor 1 dengan kriteria belum berkembang, serta tidak ada satu pun $(0 \%)$ yang memperoleh skor 4 dengan kriteria berkembang sangat baik Kegiatan pembelajaran yang dilakukan selama ini menggunakan media dan metode yang kurang sesuai.

Hasil kemampuan mengenal huruf siklus I pada indikator mampu menunjuk, menyebutkan, mengambil serta mengurutkan huruf sesuai perintah guru memperoleh persentase nilai 4,76\% (Bekembang Sangat Baik), 38,09\% (Berkembang Sesuai Harapan), 28,57\% (Mulai Berkembang), 28,57\% (Belum Berkembang). Pada siklus I masih belum memenuhi kategori dalam kemampuan mengenal lima huruf vokal, hal ini dibuktikan dengan anak yg belum bisa mendapat $57,15 \%$ sedangkan yang sudah bisa $42,85 \%$ dengan indikator mampu menunjuk, menyebutkan, mengambil serta mengurutkan huruf sesuai perintah guru.

Hasil kemampuan mengenal lima huruf vokal siklus II pada indikator mampu menunjuk, menyebutkan, mengambil serta mengurutkan huruf sesuai perintah guru memperoleh persentase nilai 14,28\% (Berkembang Sangat Baik), 47,61\% (Berkembang Sesuai Harapan), 23,80\% (Mulai Berkembang), 14,28\% (Belum Berkembang). Pada siklus II belum memenuhi kategori dalam meningkatkan kemampuan mengenal lima huruf vokal, hal ini dibuktikan dengan anak yg belum bisa mendapat 38,1\% sedangkan yang sudah bisa $61,90 \%$ dengan indikator menyebutkan, mengambil serta mengurutkan huruf sesuai perintah guru.

Hasil kemampuan mengenal lima huruf vokal siklus III pada indikator mampu menunjuk, menyebutkan, mengambil serta mengurutkan huruf sesuai perintah guru memperoleh persentase nilai 47,61\% (Bekembang Sangat Baik), 38,09\% (Berkembang Sesuai Harapan), 4,76\% (Mulai Berkembang), 9,52\% (Belum Berkembang). Pada siklus III sudah memenuhi kategori berkembang sangat baik. Hal ini dibuktikan dengan semua 
anak meningkatkan kemampuan mengenal huruf vokal mendapat $85,71 \%$ dengan hasil kategori berkembang sangat baik

\section{PEMBAHASAN}

Pada proses pembelajaran Siklus I dan II masih banyak hal-hal yang harus dibenahi diantaranya dalam menerangkan tema, dan memperbaiki media dan metode yang kurang jelas, sehingga anak-anak merasa kesulitan ketika menunjuk, menyebutkan, mengambil serta mengurutkan lima huruf vokal.

Berdasarkan persentase di atas dapat disimpulkan bahwa aktivitas guru mengalami peningkatan sebanyak $53,75 \%$, sedangkan aktivitas anak mengalami peningkatan sebesar 53,75\% dan kemampuan mengenal huruf vokal anak pada indikator mampu menunjuk, menyebutkan, mengambil serta mengurutkan huruf sesuai perintah guru pada siklus I mendapat persentase sebesar $42,85 \%$ dan pada siklus II mendapat $61,90 \%$ sedangkan pada siklus III mengalami peningkatan sebesar $85,71 \%$.

Pemantapan data pada siklus I dilakukan supaya data lebih maksimal tentang kegiatan dengan menggunakan media bola huruf. Pada siklus II dan siklus III, peneliti berusaha memperbaiki semua kegiatan pada proses pembelajaran kemampuan mengenal lima huruf vokal ini dengan cara memperbaiki medianya sehingga hasil pembelajaran sesuai yang diharapkan. Anak-anak sudah mulai menyukai kegiatan dengan menggunakan media bola huruf dan ditambah dengan meronce huruf serta menempel huruf vokal.

Keberhasilan proses pembelajaran pada siklus III ini menunjukkan bahwa siklus sudah boleh dihentikan karena sudah memenuhi target keberhasilan yaitu $75 \%$ dari jumlah anak yaitu pada aktivitas anak $86,84 \%$ dan aktivitas guru mencapai $86,84 \%$, kemampuan mengenal lima huruf vokal anak mengalami peningkatan $85,71 \%$. Melalui media bola huruf dapat meningkatkan kemampuan mengenal lima huruf vokal anak. Hal ini dapat dijadikan salah satu alternatif dalam pembelajaran untuk guru.

Media bola huruf dalam kegiatan mengenal lima huruf vokal (a-i-u-e-o) membuat anak menemukan hal baru yang belum pernah ia temukan sebelumnya. Pemilihan bola yang digunakan mandi bola dalam pembuatan bola huruf ini dikarenakan bola yang digunakan bola mandi merupakan jenis bola yang berbahan plastik yang memiliki corak warna yang beragam dan mencolok sehingga anak lebih tertarik melakukan kegiatan pembelajaran. Juga mudah mencari bahannya serta praktis dalam penyimpanannya, cara pembuatannyapun mudah sehingga siapa saja dapat membuatnya serta dapat disesuaikan dengan tujuan kegiatan pembelajaran.

\section{SIMPULAN DAN SARAN Simpulan}

Berdasarkan hasil penelitian dan pembahasan tentang peningkatan kemampuan mengenal lima huruf vokal dengan media bola huruf pada anak usia 3-4 tahun Playgroup dan Taman Kanak-kanak Aisyiyah Bustanul Athfal Ketegan Taman Sidoarjo, dapat disimpulkan sebagai berikut: 1) Penggunaan media bola huruf efektif bila ditambah dengan media meronce huruf dan media menghias gelas plastik dengan huruf vokal, hal ini dikarenakan media tersebut dapat membantu anak dalam mengenal lima huruf vokal. Dengan media meronce dapat membantu anak dalam mengenal, mengambil, mengurutkan, dan menyebutkan huruf vokal, sedangkan dengan media menghias gelas plastik dapat membantu anak dalam menunjuk dan menyebutkan huruf serta mengambil dan mengurutkan huruf vokal. Hal ini dapat dilihat pada hasil observasi aktivitas guru 
dan aktivitas anak pada siklus I meningkat dari 53,75\% (Cukup) menjadi 64,47\% (Baik) dan Sangat baik pada siklus III yaitu $86,84 \%$. Sama halnya dengan aktivitas anak juga meningkat dari siklus I sebesar 53,75\% (Mulai Berkembang) menjadi 64,47\% (Berkembang Sesuai Harapan) dan berkembang sangat baik pada siklus III yaitu $86,84 \%$; 2) Peningkatan kemampuan mengenal lima huruf vokal setelah digunakannya media bola huruf dan ditambah media meronce dan menghias gelas plastik denga stiker huruf vokal terjadi peningkatan, hal ini terlihat dari hasil ketuntasan anak mengenal lima huruf vokal yaitu pada prasiklus 0\% (Bekembang Sangat Baik), 19,04\% (Berkembang Sesuai Harapan), 52,38\% (Mulai Berkembang), 28,57\% (Belum Berkembang), dengan rata-rata 23,80, Siklus I 4,76\% (Bekembang Sangat Baik), 38,09\%(Berkembang Sesuai Harapan), 28,57\% (Mulai Berkembang), 28,57\% (Belum Berkembang) dengan rata-rata 54,16, dan pada siklus II ketuntasan belajar 14,28\% (Berkembang Sangat Baik), 47,61\% (Berkembang Sesuai Harapan), 23,80\% (Mulai Berkembang), 14,28\% (Belum Berkembang), rata-rata 67,26, sedangkan pada siklus III ketuntasan belajar 47,61\% (Bekembang Sangat Baik), 38,09\% (Berkembang Sesuai Harapan), 4,76\% (Mulai Berkembang), 9,52\% (Belum Berkembang) dengan rata-rata 82,73.

Saran

Dengan memperhatikan kesimpulan di atas, maka beberapa saran yang dikemukakan antara lain bagi Guru. Guru hendaknya lebih memperhatikan kondisi anak dalam mengikuti proses pembelajaran, agar dapat diketahui apakah siswa menyukai cara guru dalam mengajar. Hal ini dikarenakan sudah banyak sekali metode, strategi, media yang sudah berkembang di dunia pendidikan, hanya saja gurunya yang perlu menerapkan lagi dalam proses pembelajaran agar anak menjadi aktif belajar di kelas. Perhatian kepada anak juga perlu ditingkatkan, karena pada saat penelitian berlangsung, peneliti menemukan terdapat tiga anak yang belum mengenal lima huruf vokal.

Bagi Sekolah penggunaan media bola huruf diharapkan dapat diterapkan secara berkesinambungan oleh guru agar anak lebih aktif dalam belajar di sekolah. Bagi Peneliti Selanjutnya, hasil penelitian ini dapat dijadikan sebagai referensi bagi penelitian lain yang terkait dengan peningkatan kemampuan mengenal huruf lima vokal pada anak usia 3-4 tahun..

\section{AKNOWLEDGMENT} Sidoarjo.

Peneleitian ini di dukung oleh PG-TK Aisyiyah Bustanul Athfal Ketegan Taman

\section{DAFTAR RUJUKAN}

Arikunto, Suharsimi. (2010). Prosedur Penelitian Suatu Pendekatan Praktik. Jakarta: Rineka Cipta.

Asmawati, Luluk, et al. (2017). Pengelolaan Kegiatan Pengembangan Anak Usia Dini. Tangerang Selatan: Universitas Terbuka.

Hamim, Nur dan Husniyatus Salamah Zainiyati. (2009). Penelitian Tindakan Kelas. Surabaya: PT Revka Petra Media.

Manan, Sholihin. (1999). Pengantar Kaidah Berbahasa Indonesia yang Baik dan Benar. Surabaya: Jurusan PAI Fak. Tarbiyah IAIN Surabaya.

Team Dafa Publishing. (2010). Mengajari Bayi Membaca. Yogyakarta: Dafa Publishing. 
Subagyo, Joko. (2006). Metode Penelitian dalam Teori dan Praktek. Jakarta: PT Rineka Cipta.

Susanto, Ahmad. (2012). Perkembangan Anak Usia Dini: Pengantar dalam Berbagai Aspeknya. Jakarta: Kencana.

\section{AUTHOR}

Siti Karoma, dilahirkan di Sidoarjo, 25 April 1996, anak ke empat dari tiga bersaudara, pasangan dari Bapak Sudarsono dan Ibu Ainun Alfiah. Pendidikan Pertama ditempuh di TK Muslimat NU Ketegan selama 2 Tahun dan tamat pada tahun 2002. Pendidikan Dasar ditempuh di SD Ma'arif Ketegan selama 6 tahun dan tamat pada tahun 2008. Pendidikan Menengah Pertama ditempuh di SMP Muhammadiyah 2 Taman selama 3 tahun dan tamat pada tahun 2011. Kemudian meneruskan pada jenjang Pendidikan Menengah Atas di SMA Negeri 1 Taman selama 3 tahun dan tamat pada tahun 2014. Pendidikan berikutnya ditempuh di Program Studi Pendidikan Islam Anak Usi Dini Fakultas Tarbiyah dan Keguruan UIN Sunan Ampel Suraabaya selama 4 tahun dan tamat pada tahun 2018 